\title{
KARAKTERISTIK BENTENG VASTENBERG SEBAGAI BANGUNAN HERITAGE DI SURAKARTA
}

\author{
Risang Raditya, Dhani Mutiari \\ Program Studi Teknik Arsitektur, Fakultas Teknik, Universitas Muhammadiyah Surakarta \\ Jl. A. Yani Tromol Pos 1 Pabelan Kartasura Sukoharjo 57102 Telp 0271-717417 \\ E-mail: dhani.mutiari@yahoo.com
}

\begin{abstract}
ABSTRAK
Penelitian ini membahas tentang pentingnya konservasi Kota Surakarta sebagai salah satu kota kolonial di Indonesia. Kota merupakan cerminan dari sejarah masa lalu, melalui keragaman bangunan dari masa lalu , sekarang dan mendatang akan terlihat jejak jejak kehidupan peristiwa yang terjadi di Kota Surakarta. Penelitihan ini bertujuan untuk menginventarisasi karakteristik benteng Vastenberg sebagai bangunan heritage di Surakarta. Metode analisis yang digunakan deskriptif yaitu sample purposive dari hasil pengamatan, baik pengamatan secara langsung yaitu pengamatan di lapangan dan pengamatan tak langsung yaitu melalui literatur dan wawancara. Hasil dari penelitian ini adalah Benteng Vastenberg memiliki bentuk site plan berbentuk atau menyerupai kura-kura yang mana merupakan benteng pertahanan, .parit pertahanan, gerbang utama yang kokoh berornamen lengkung dan terdapat tulisan nama benteng diatasnya., Tembok selubung / tepung gelang yang berfungsi melindungi bangunan utama dan orang didalamnya dari serangan musuh dan memiliki kesamaan ornament dengan bangunan utama Keraton Kasunanan Surakarta Hadiningrat
\end{abstract}

\section{Kata Kunci: konservasi, karakteristik, benteng}

\section{PENDAHULUAN}

Kota Surakarta memiliki potensi yang sangat besar pada sosio kultural yang sering dikenal dengan sebutan 'Wong Solo' yang halus perilakunya. Dahulu, Kota Surakarta memiliki bangunan maupun tempat terkenal dan nyaman, keindahan legendaries Taman Jurug, Taman Sriwedari, Taman Balekambang dan Benteng Vastenburg, yang menunjukkan bahwa sejak dulu Kota Surakarta telah memiliki arah pembangunan fisik lingkungan terutama penyediaan lahan atau lingkungan untuk interaksi warga masyarakatnya.

Menurut Eko Budihardjo (1997), pentingnya Konservasi Kota Surakarta sebagai salah satu kota kolonial di Indonesia. Kehidupan masyarakat dan penguasa di Surakarta dalam masa sebelum kemerdekaan 1945 membentuk suatu sistem keterkaitan. Sistem keterkaitan tersebut tidak saja dalam struktur pemerintahan kerajaan akan tetapi berbaur dan saling mempengaruhi dengan orang-orang Belanda, Eropa, Cina dan Arab maupun dari luar Kota Surakarta yang didatangkan sebagai tenaga kerja. Sistem kehidupan ini berproses cukup lama dari tahun 1746 sampai 1945, sehingga membentuk sebuah tatanan yang mengakibatkan terbentuknya struktur kota.

Menurut Sidharta dan Eko Budihardjo (2000) , unsur-unsur Kota Surakarta yang berdirinya untuk kepentingan peri kehidupan kolonial Belanda yaitu :

1. Kampung baru, meliputi : Benteng Vastenburg, kantor Residen,Gereja St.Antonius, Bunderan Sekolah Lanjutan MULO, Bioskop, Kantor Pos, Javasche Bank.

2. Kampung Eropa di Jebres

3. Komplek villa park di Banjar sari

4. Komplek lapangan pacuan kuda Manahan

5. Komplek Stasiun Purwosari

6. Komplek rumah dinas Asisten Residen Penumping

Pada masa pemerintahan kerajaan di Surakarta, unsur-unsur Belanda membentuk sistem berdasarkan kepentingan mereka. Benteng Vastenburg berperan sebagai pusat pertahanan keamanan; Komplek ini juga 
berfungsi sebagai, pusat perkantoran Belanda. Perkantoran yang dianggap penting saat itu adalah Javasche Bank dan Kantor Pos. Bangunan kolonial di Kota Surakarta sangat banyak tetapi rusak dan mulai hancur. Salah satu contoh nyata adalah tidak terawatnya situs bangunan Benteng Vastenburg peninggalan Belanda. Benteng Vastenburg memiliki kaitan posisi dengan Kraton Kasunanan dan rumah Gubernur Belanda (Kantor Balaikota) di kawasan Gladak. Peninggalan-peninggalan tersebut berupa bangunan kolonial yang perlu dipertahankan keberadaannya dan dipelihara sebagai bukti dari sisi perjuangan bersejarah. Pada perkembangannya bangunan peninggalan tersebut merupakan asset pariwisata yang potensial.

Metode analisis yang digunakan Deskriptif yaitu sample purposive dari hasil pengamatan, baik pengamatan secara langsung yaitu pengamatan di lapangan dan pengamatan tak langsung yaitu melalui literatur dan wawancara

\section{TINJAUAN PUSTAKA}

Benteng adalah bangunan untuk keperluan militer yang dibuat untuk keperluan pertahanan sewaktu dalam peperangan. Benteng sudah dibangun oleh umat manusia sejak ribuan tahun yang lalu dalam berbagai bentuk dan pada akhirnya berkembang menjadi bentuk yang sangat komplek (www.wikipedia.com)

Pada masa penjajahan Belanda banyak bangunan benteng yang tersebar diseluruh nusantara dengan fungsi sebagai keperluan Pemerintahan Kolonial Belanda antara lain untuk pertahanan, peristirahatan, pusat pemerintahan, gudang senjata, penjara bagi para pemberontak, dan tempat latihan para prajurit Belanda. Sekarang ini bangunan benteng peninggalan Pemerintahan Belanda tersebar diseluruh Nusantara dan telah memiliki fungsi yang berbeda-beda. Setiap daerah yang diwarisi memiliki rasa kepedulian yang berbeda akan situs sejarah tersebut. Diantaranya adalah sebagai berikut :

\section{a. Benteng Fort Rotterdam}

Benteng yang terletak di daerah Ujung Pandang ini adalah sebuah benteng peninggalan Kerajaan Gowa-Tallo. Letak benteng ini berada di pinggir pantai sebelah barat Kota Makassar, Sulawesi Selatan.

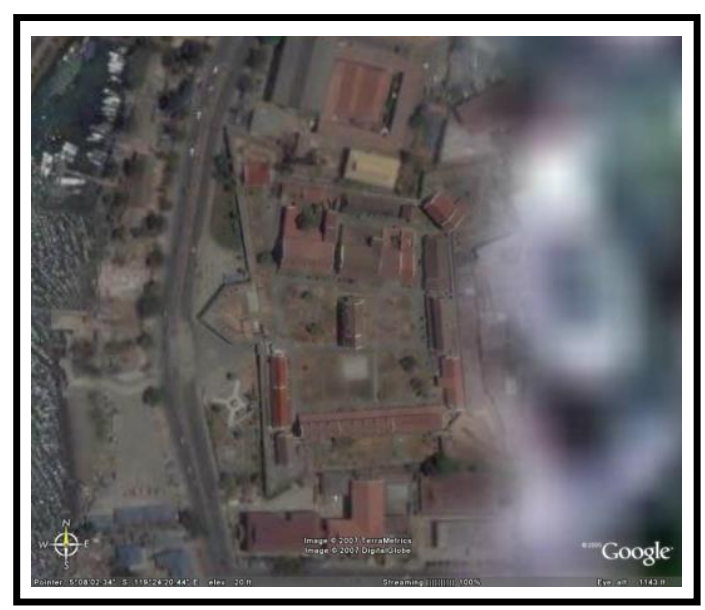

Gambar 1. Lokasi Benteng Fort Rotterdam Sumber Wikipedia, 2009

Benteng ini dibangun pada tahun 1545 oleh Raja Gowa ke-9 yang bernama I manrigau Daeng Bonto Karaeng Lakiung Tumapa'risi' Kallonna. Awalnya benteng ini berbahan dasar tanah liat, namun pada masa pemerintahan Raja Gowa ke-14 Sultan Alauddin konstruksi benteng ini diganti menjadi batu padas yang bersumber dari pegunungan karst yang ada di daerah Maros. Benteng Ujung Pandang ini berbentuk seperti seekor penyu yang hendak merangkak turun ke lautan. Dari segi bentuknya sangat jelas filosofi Kerajaan Gowa, bahwa penyu dapat hidup di darat maupun di laut. Begitupun dengan Kerajaan Gowa yang berjaya di daratan maupun di lautan.

Nama asli benteng ini adalah Benteng Ujung Pandang, biasa juga orang GowaMakassar menyebut benteng ini dengan sebutan Benteng Panyyua yang merupakan markas pasukan katak Kerajaan Gowa. Kerajaan Gowa-Tallo akhirnya menandatangani perjanjian Bungayya yang salah satu pasalnya mewajibkan Kerajaan Gowa untuk menyerahkan benteng ini kepada Belanda yang kemudian namanya diubah menjadi Fort Rotterdam. Cornelis Speelman sengaja memilih nama Fort Rotterdam untuk mengenang daerah kelahirannya di Belanda. Benteng ini kemudian digunakan oleh Belanda sebagai pusat penampungan rempah-rempah di Indonesia bagian timur. 


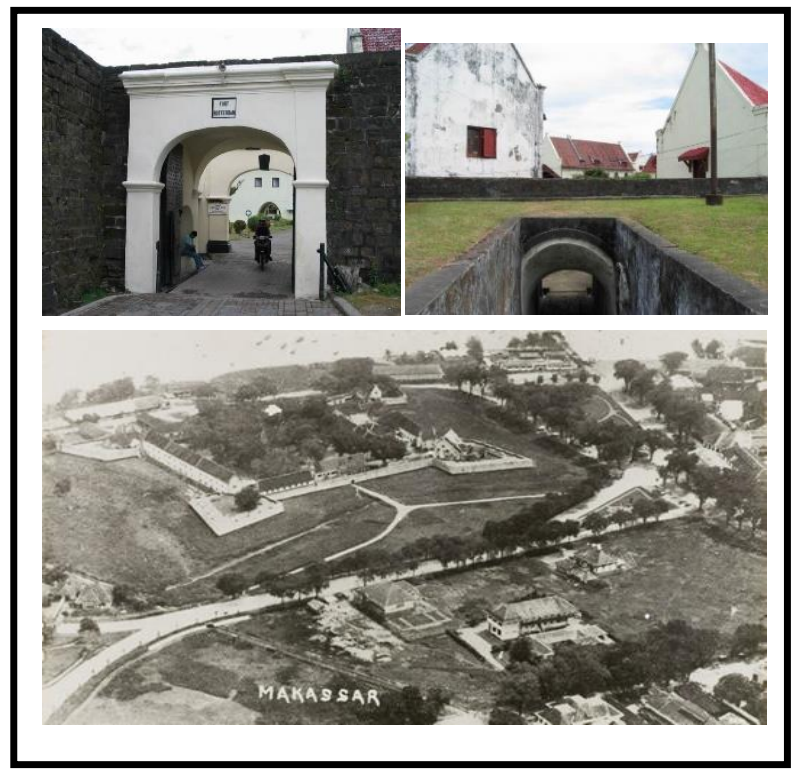

Gambar 2. Karakteristik Benteng Fort Rotterdam Sumber : wikipedia, 2009

Di kompleks Benteng Ujung Pandang kini terdapat Museum La Galigo yang di dalamnya terdapat banyak referensi mengenai sejarah kebesaran Makassar (Gowa-Tallo) dan daerah-daerah lainnya yang ada di Sulawesi Selatan. Sebagian besar gedung benteng ini masih utuh dan menjadi salah satu objek wisata di Kota Makassar.

\section{b. Benteng Pendem Cilacap}

Benteng Pendem Cilacap yang dibangun pada tahun 1861, adalah benteng peninggalan Belanda di pesisir pantai Teluk Penyu Kabupaten Cilacap, Jawa Tengah

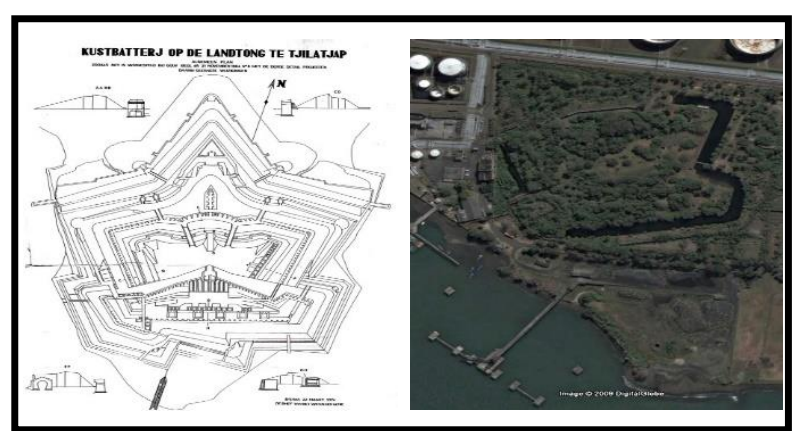

Gambar 3. Benteng Pendem Cilacap Sumber Wikipedia, 2009

Bangunan ini merupakan bekas markas pertahanan tentara Hindia Belanda yang dibangun di area seluas 6,5 hektar secara bertahap selama 18 tahun, dari tahun 1861 hingga 1879. Benteng pendem sempat tertutup tanah pesisir pantai dan tidak terurus. Benteng ini kemudian ditemukan dan mulai digali pemerintah Cilacap tahun 1986. Benteng Pendem dahulunya merupakan markas pertahanan tentara Belanda di Cilacap, Jawa Tengah yang didesain oleh arsitek Belanda. Benteng Pendem difungsikan hingga tahun 1942. Ketika perang malawan Pasukan Jepang, benteng ini berhasil dikuasai Jepang. Tahun 1941, tetapi kemudian ditinggalkan ketika kota Hiroshima dan Nagasaki dibom oleh sekutu. Setelah peristiwa ini benteng diambil alih oleh TNI Banteng Loreng Kesatuan Jawa Tengah dan digunakan para pejuang kemerdekaan untuk berlatih perang dan pendaratan laut.

Bangunan benteng pendem terdiri dari beberapa ruang yang masih kokoh hingga kini, namun sejak awal ditemukan, ruangan dalam benteng belum sepenuhnya diketahui. Ruangan dalam benteng yang umum

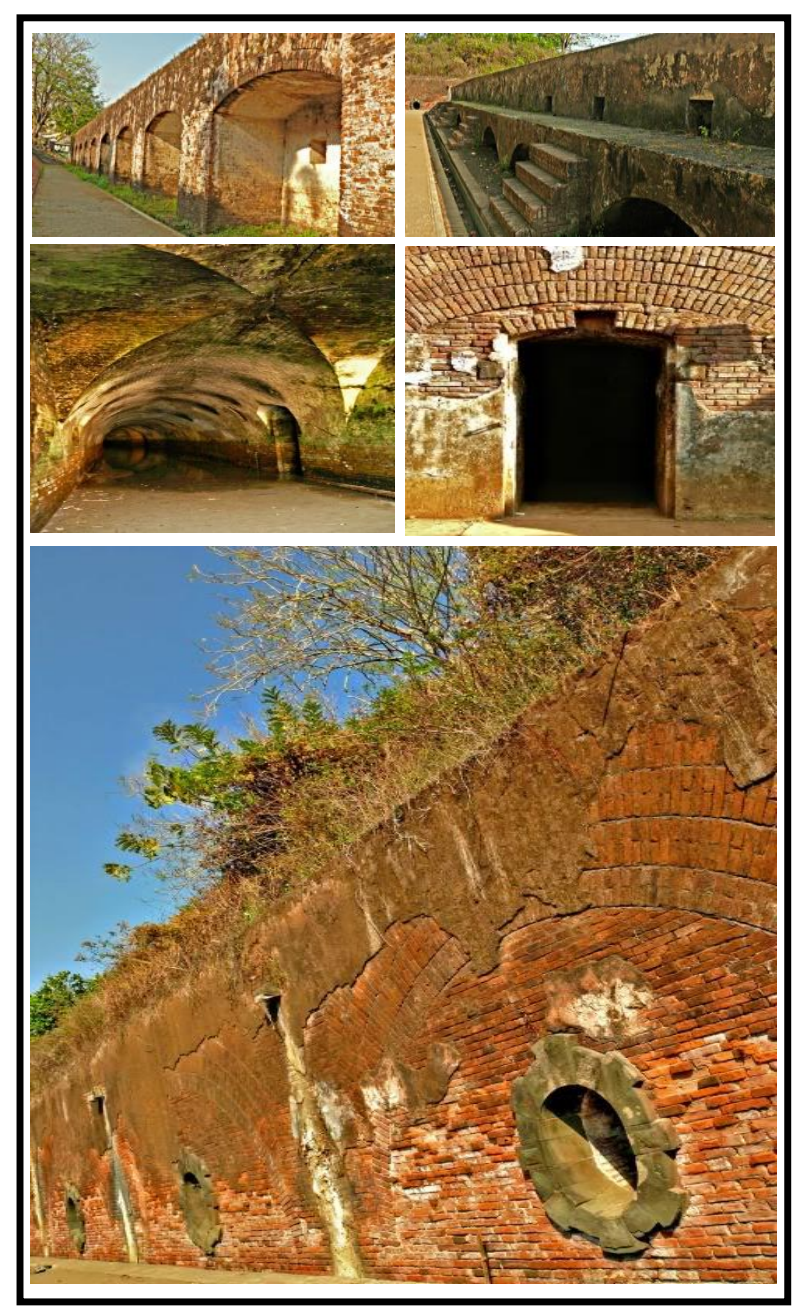

Gambar4. Karakteristik Benteng Pendem Cilacap Sumber Wikipedia, 2009 
diketahui terdiri dari barak, benteng pertahanan, benteng pengintai, ruang rapat, klinik pengobatan, gudang senjata, gudang mesiu, ruang penjara, dapur, ruang perwira, dan ruang peluru. Ada pula yang menyatakan bahwa dalam benteng tersebut terdapat terowongan menuju benteng-benteng lain dan sejumlah gua di pulau Nusakambangan, namun, hingga kini hal itu belum sepenuhnya terbukti.

\section{c. Benteng Van Der Wijck}

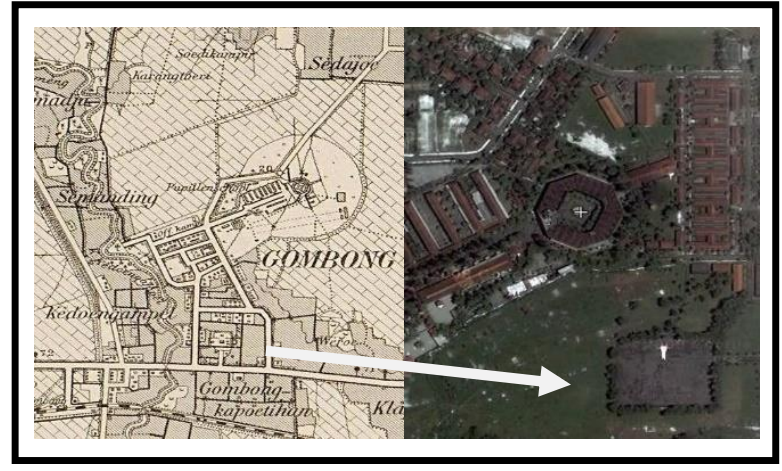

Gambar 5. Benteng Van Der Wijk Sumber Wikipedia, 2009

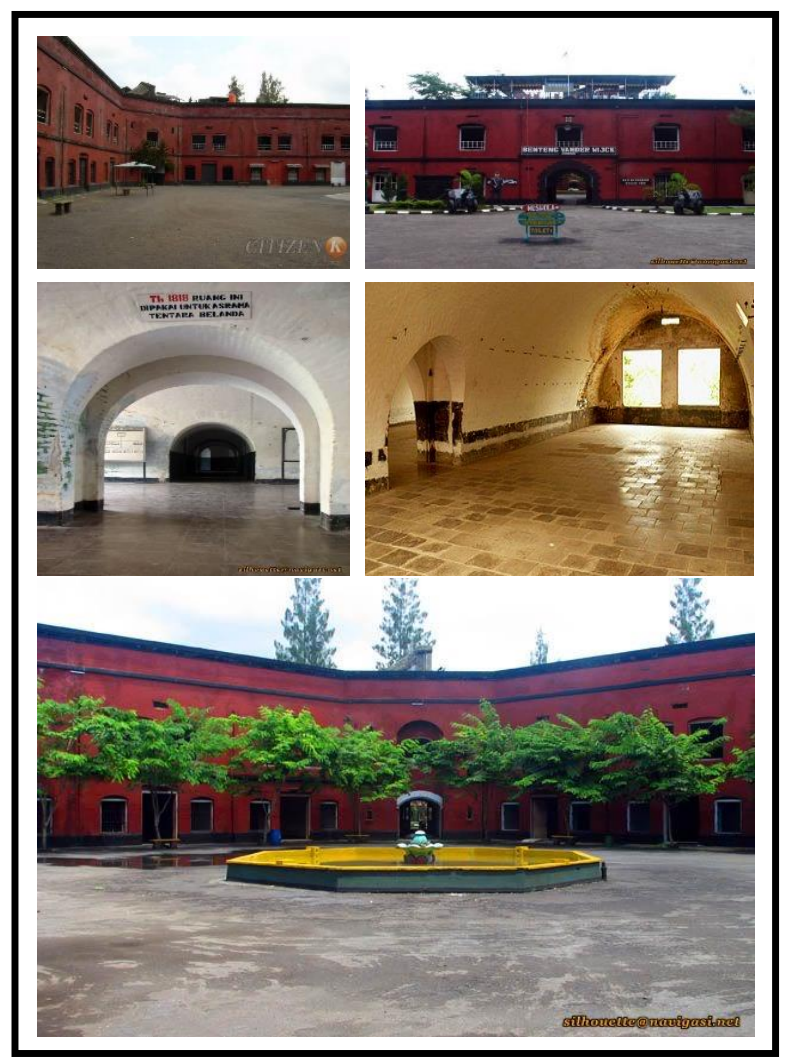

Gambar 6. Karakteristik Benteng Van Der Wijk Sumber Wikipedia, 2009
Benteng Van Der Wijck merupakan Benteng pertahanan Hindia-Belanda yang dibangun pada abad ke 18. Benteng ini terletak di Gombong, sekitar $21 \mathrm{~km}$ dari kabupaten Kebumen, Jawa Tengah, atau 100 $\mathrm{km}$ dari Candi Borobudur, Magelang, Jawa Tengah. Nama benteng ini diambil dari Van Der Wijck, nama komandan pada saat itu. Benteng ini kadang dihubungkan dengan nama Frans David Cochius (1787-1876), seorang jenderal yang bertugas di daerah Barat Bagelen yang namanya juga diabadikan menjadi nama Benteng Generaal Cochius.

\section{d. Benteng Fort Vredeburg}

Benteng Fort Vredeburg adalah sebuah benteng yang dibangun oleh Belanda di Yogyakarta selama masa kolonial. Terletak di depan Gedung Agung, satu dari tujuh istana kepresidenan di Indonesia dan Istana Sultan yang dinamakan Kraton. Dibangun pada tahun 1765 untuk melindungi gubernur Belanda. Benteng ini dikelilingi oleh sebuah parit yang masih bisa terlihat dan berbentuk persegi serta mempunyai menara pantau di keempat sudutnya. Di masa lalu, tentara Belanda sering berpatroli mengelilingi dindingnya. Sekarang, benteng ini menjadi sebuah museum dengan sejumlah bangunan di dalamnya terdapat diorama mengenai sejarah Indonesia.

Museum Benteng Yogyakarta, semula bernama "Benteng Rustenburg" yang mempunyai arti "Benteng Peristirahatan" , dibangun oleh Belanda pada tahun 1760 di atas tanah Keraton. Berkat izin Sri Sultan Hamengku Buwono I, sekitar tahun 1765 1788 bangunan disempurnakan dan selanjutnya diganti namanya menjadi "Benteng Vredeburg" yang mempunyai arti "Benteng Perdamaian".Secara historis bangunan ini sejak berdiri sampai sekarang telah mengalami berbagai perubahan fungsi yaitu pada tahun 1760 - 1830 berfungsi sebagai benteng pertahanan, pada tahun 1830 -1945 berfungsi sebagai markas militer Belanda dan Jepang, dan pada tahun 1945 1977 berfungsi sebagai markas militer RI.

Setelah tahun 1977 pihak Hankam mengembalikan kepada pemerintah. Oleh pemerintah melalui Mendikbud yang saat itu dijabat Bapak Daoed Yoesoep atas persetujuan Sri Sultan Hamengku Buwono IX selaku pemilik, ditetapkan sebagai pusat 
informasi dan pengembangan budaya nusantara pada tanggal 9 Agustus 1980.Pada tanggal 16 April 1985 dipugar menjadi Museum Perjuangan dan dibuka untuk umum pada tahun 1987.

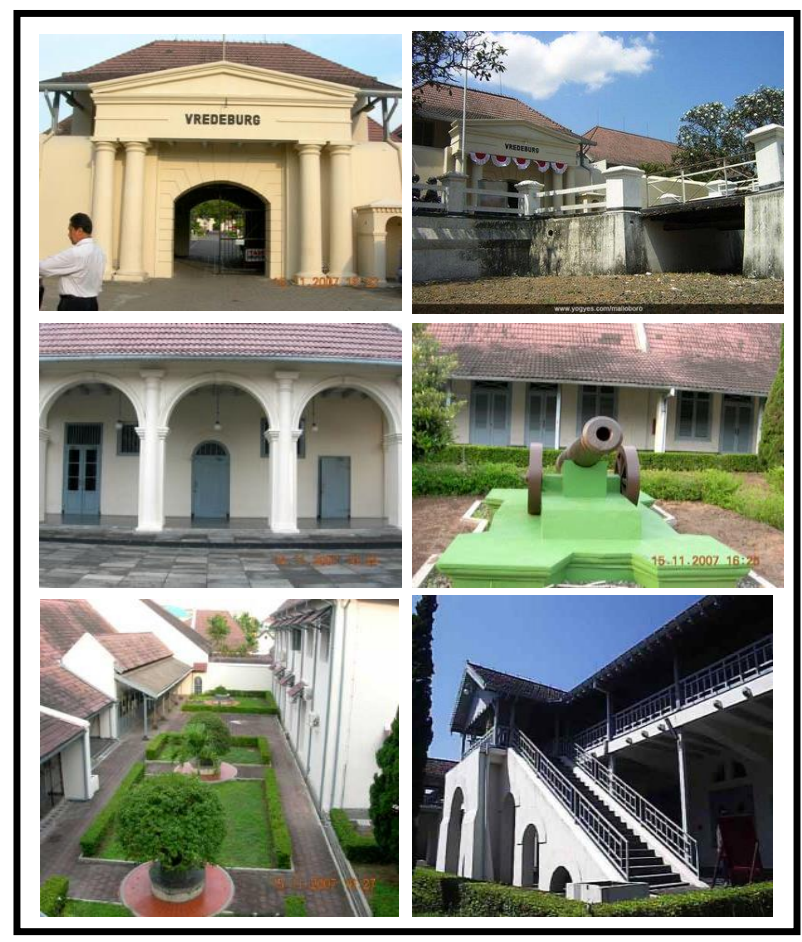

Gambar 7. Karakteristik Benteng Fort Vredeburg Sumber : Wikipedia, 2009

Kemudian pada tanggal 23 November 1992 resmi menjadi "Museum Khusus Perjuangan Nasional" dengan nama "Museum Benteng Yogyakarta". Bangunan bekas Benteng Vredeburg dipugar dan dilestarikan. Dalam pemugaran pada bentuk luar masih tetap dipertahankan, sedang pada bentuk bagian dalamnya dipugar dan disesuaikan dengan fungsinya yang baru sebagai ruang museum.

\section{METODE PENELITIAN}

a. Metode Pengumpulan Data :

Metode ini dilakukan dengan wawancara, observasi langsung dan dokumentasi. Wawancara dilakukan kepada nara sumber terhadap data yang belum terungkap dilapangan. Metode observasi langsung dilakukan guna mendapatkan data secara langsung bagaimana kondisi fisik yang ada tanpa adanya suatu rekayasa tertentu. Dokumentasi dilakukan melalui media internet untuk mendapatkan suatu data yang kurang untuk di tambahkan ke dalam penelitian tersebut dan mendapatkan suatu kemudahan dalam hal perolehan data tanpa harus mengamati secara langsung.

b. Alat Penelitian :

Alat yang digunakan untuk pengumpulan data adalah: kamera, alat tulis/alat gambar, kertas gambar, computer, gambar, dan meteran

c. Variabel Penelitian :

Segala sesuatu yang akan menjadi objek pengamatan penelitian dan merupakan faktor-faktor yang berperan dalam peristiwa atau gejala yang akan diteliti. Adapun faktor-faktor yang berpengaruh ialah :
a) Bentuk site plan benteng
b) Parit pertahanan benteng
c) Bentuk gerbang utama
d) Tembok selubung pertahanan benteng
e) Bastion pertahanan benteng
f) Bangunan utama benteng

d. Metode Analisis Data :

Dengan metode pengumpulan diatas maka peneliti mendapatkan sebuah data mentah, kemudian diolah dengan cara analisis pembandingan dari penetapan batas sampel data pembanding dengan data yang akan diteliti. Dengan mengacu pada variabel penelitian tersebut yang mana merupakan sebuah faktor-faktor yang berperan dalam peristiwa atau gejala yang akan diteliti. Adapun hal-hal yang perlu diperhatikan dalam melakukan analisis data adalah:

a) Membuat memo atau rangkuman data.

b) Mengujicobakan beberapa data yang ada dari sampel data untuk di bandingkan ke objek penelitian tersebut.

c) Mengkaji dari literature sejarah baik melalui kepustakaan ataupun lewat media internet. 


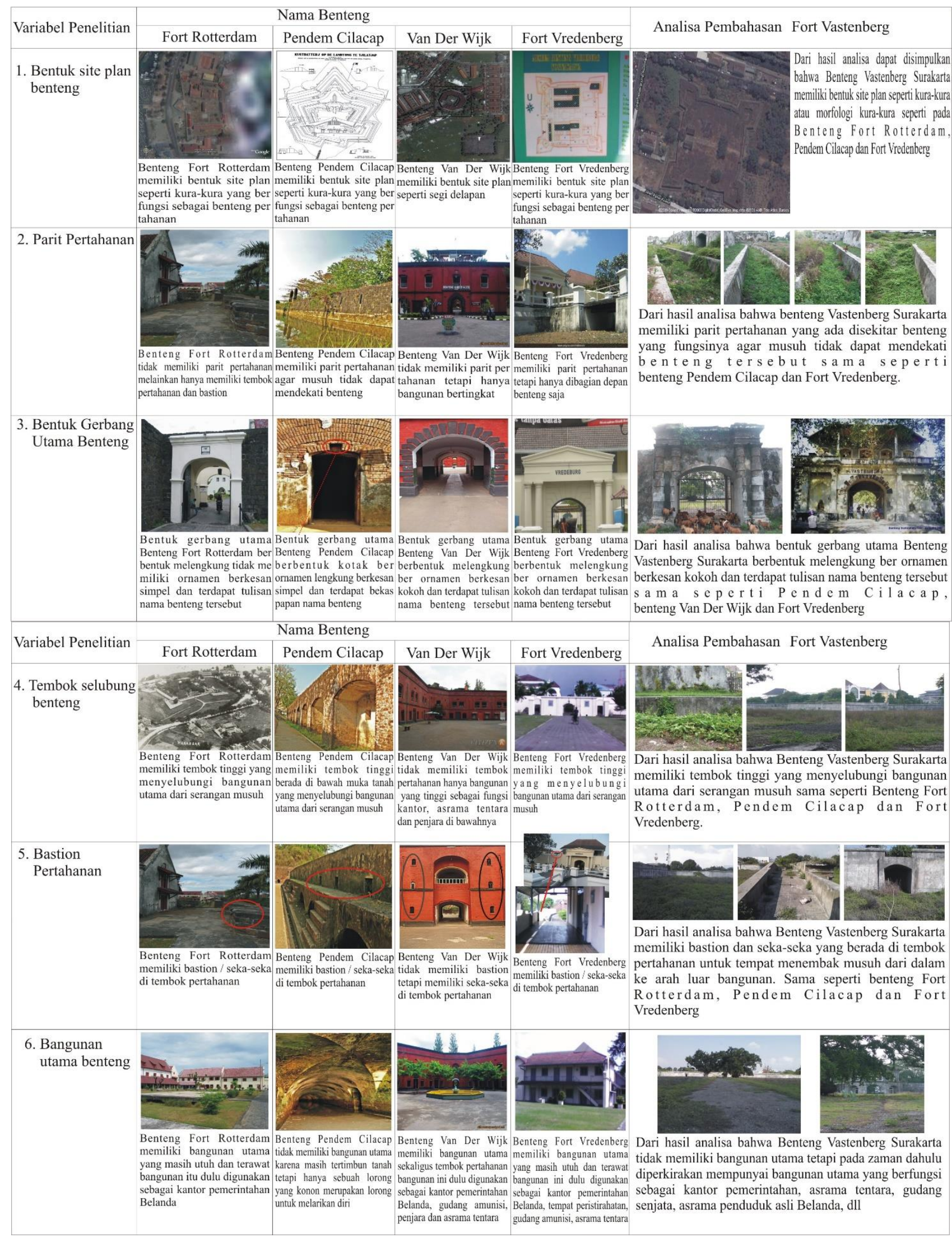

Gambar 8. Perbandingan Karakteristik Benteng yang Berada di Indonesia Sumber : Analisis, Tahun 2010 
TEMUAN PENELITIAN

a. Perbandingan Benteng peninggalan

Belanda di Indonesia.

Penelusuran pustaka dan dokumentasi dilakukan terhadap empat benteng yang terdapat di Indonesia yaitu : Benteng Fort Rotterdam di Ujung Pandang, Benteng Pendem Cilacap, Benteng Van Der Wijck di daerah Gombong dan Benteng Fort Vredeburg di Yogyakarta. Keempat benteng ini digunakan sebagai bahan kajian dan perbandingan terhadap karakteristik Benteng Vasternberg yang berada di Surakarta. Elemen yang diamati adalah : bentuk site plan, parit pertahanan, pintu gerbang utama, benteng selubung, bastion pertahanan dan bangunan utama . (lihat gambar 8).

\section{b. Karakteristik Benteng Vastenberg di Surakarta}

Dari hasil perbadingan diatas maka ditemukan bahwa pada Benteng Vastenberg a). Terdapat sebuah prasasti yang melekat di lorong gerbang utama sebelah barat Benteng dilihat dari sejarah tersebut, maka jelas bangunan ini termasuk bagian sejarah bangsa Indonesia dan khususnya bagian dari sejarah kota Surakarta.

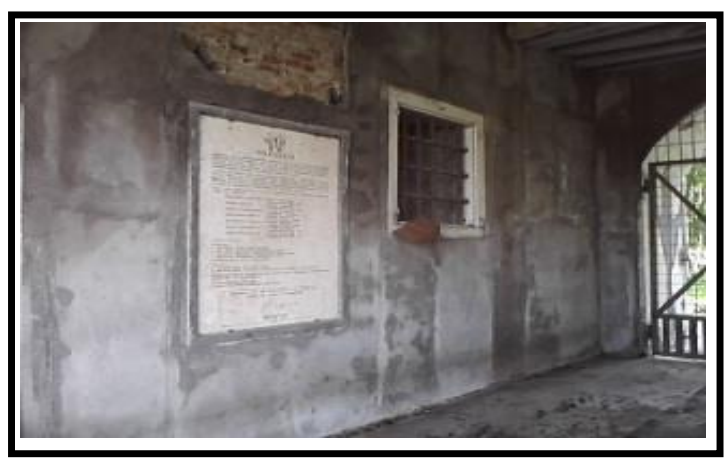

Gambar 9.Prasasti Benteng Vastenberg Sumber ; Dokumentasi pribadi, 2009

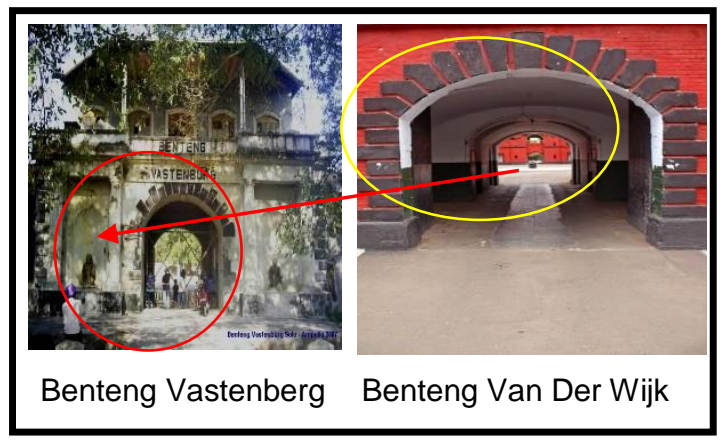

Gambar 10. Pintu Gerbang utama Benteng Vastenberg

Sumber : Analisis, 2010 b). Terdapat kesamaan ornament yang digunakan pada pintu depan Benteng Vastenberg Surakarta dengan Benteng Van Der Wijk Kebumen

c). Terdapat kesamaan bentuk motif atap dan kruwing atap pada tempat penjagaan Benteng Vastenberg dengan bentuk motif atap dan kruwing atap pintu gerbang utama pada Keraton Kasunanan Surakarta Hadiningrat dan juga sebagai tempat penjagaan prajurit Keraton.

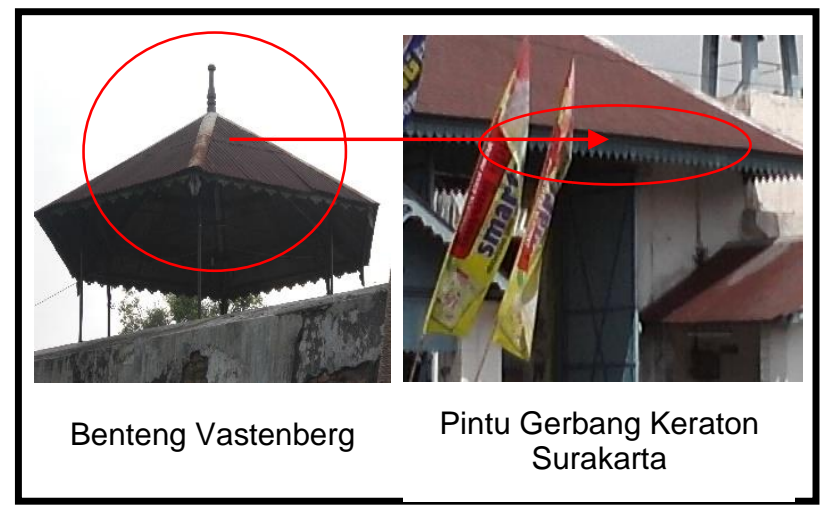

Gambar 11. Karakteristik bentuk motif kawungpada atap Sumber : Analisis, 2010

d). Terdapat patung penjaga di Gerbang utama sebelah barat Benteng Vastenberg sama dengan pada Keraton Kasunanan Surakarta Hadiningrat yang mana symbol arca tersebut sebagai penjaga pintu gerbang utama.

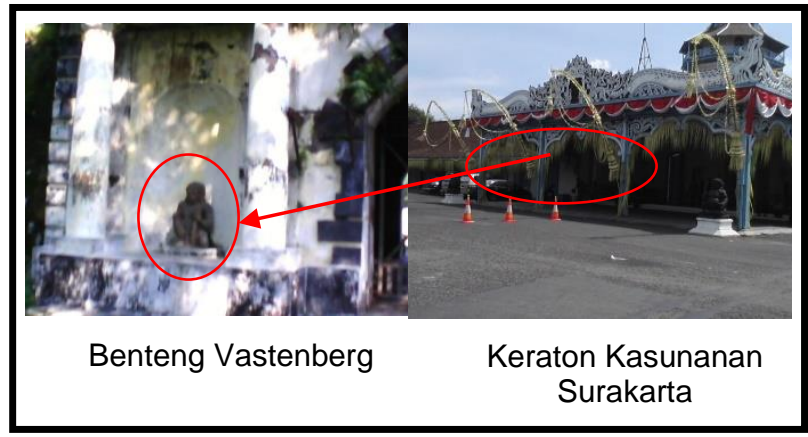

Gambar 12. Patung penjaga gerbang Sumber : Analisis, 2010

\section{KESIMPULAN DAN SARAN Kesimpulan}

\section{a. Karakteristik Benteng Vastenberg}

Berdasarkan hasil penelitian dari perbandingan bangunan benteng di atas terhadap bangunan benteng Vastenberg di 
Surakarta, dapat di ambil kesimpulan sebagai berikut :

1. Benteng Vastenberg Surakarta memiliki bentuk site plan berbentuk atau menyerupai kura-kura yang mana merupakan benteng pertahanan.

2. Benteng Vastenberg Surakarta memiliki parit pertahanan yang berada disekeliling bangunan benteng guna mempertahankan kekuatan dan melindungi jembatan arah Barat-Timur dari musuh.

3. Benteng Vastenberg Surakarta memiliki gerbang utama yang kokoh berornamen lengkung dan terdapat tulisan nama benteng diatasnya.

4. Benteng Vastenberg Surakarta memiliki tembok selubung / tepung gelang yang berfungsi melindungi bangunan utama dan orang didalamnya dari serangan musuh

5. Benteng Vastenberg Surakarta memiliki teknik perang bastion / seleka (penonjolan di ujung-ujungnya).

6. Benteng Vastenberg Surakarta tidak memiliki bangunan utama tetapi pada jaman dahulu mempunyai bangunan utama yang berfungsi sebagai kantor pemerintahan Belanda, gudang amunisi, pertahanan orang-orang Belanda, asrama tentara. Di bawah ini gambar Benteng Vastenberg tempo doeloe:

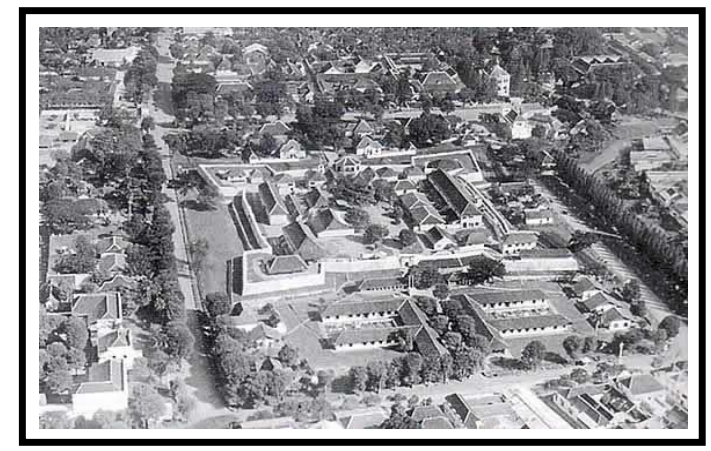

Gambar 13. Benteng Vastenberg Sumber : Wikipedia, 2009

\section{b. Elemen-elemen Heritage Benteng Vastenberg}

Berdasarkan hasil penelitian dari perbandingan bangunan benteng $d i$ atas terhadap bangunan benteng Vastenberg di Surakarta, dapat di ambil kesimpulan sebagai berikut :
1. Bentuk site plan Benteng Vastenberg dari morfologi kura-kura yang mana merupakan istilah teknik perang yang di sisi-sisi ujungnya terdapat penonjolan (seleka) atau bastion.

2. Parit pertahanan yang mengelilingi Benteng berfungsi menghalau musuh yang akan mendekati bangunan.

3. Adanya pintu gerbang di sebelah Barat dan Timur pada benteng agar sirkulasi keluar masuk di dalam benteng terjaga dan terhindar dari penyusupan.

4. Benteng Vastenberg Surakarta memilikii tembok selubung / tepung gelang yang berfungsi melindungi bangunan utama dan orang didalamnya dari serangan musuh

5. Terdapat sebuah prasasti yang melekat di lorong gerbang utama sebelah Barat Benteng Vastenberg dilihat dari sejarah tersebut, maka jelas bangunan ini termasuk bagian sejarah bangsa Indonesia dan khususnya bagian dari sejarah kota Surakarta.

6. Terdapat kesamaan ornament yang digunakan pada pintu belakang sebelah Timur Benteng Vastenberg Surakarta dengan Benteng Malborough yang mana kedua benteng tersebut berbeda masa penjajahan, benteng vastenberg pada masa penjajahan Belanda sedangkan Benteng Malborogh masa penjajahan Inggris di kota Bengkulu.

7. Terdapat kesamaan ornament yang digunakan pada pintu depan Benteng Vastenberg Surakarta dengan Benteng Van Der Wijk Kebumen

8. Terdapat kesamaan bentuk motif atap dan kruwing atap pada tempat penja-gaan Benteng Vastenberg dengan bentuk motif atap dan kruwing atap pintu gerbang utama pada Keraton Kasunanan Surakarta Hadiningrat dan juga sebagai tempat penjagaan prajurit Keraton.

9. Terdapat patung arca penjaga di gerbang utama sebelah Barat Benteng Vastenberg sama dengan pada Keraton Kasunanan Surakarta Hadiningrat yang mana simbol arca tersebut sebagai penjaga pintu gerbang utama. 
Saran

Melihat dari karakteristik Benteng Vastenberg yang unik maka disarankan agar benteng yang tinggal selubungnya ini dapat dilestarikan. Jika terdapat perencanaan bangunan baru yang terdapat di dalam benteng diupayakan untuk dapat memiliki bentuk yang mendukung keberadaan benteng yang dilestarikan.

\section{DAFTAR PUSTAKA}

Budihardjo, 1997. Arsitektur Pembangunan dan Konservasi. Djambatan, Jakarta

Sidharta, Eko Budiharjo, 2000,. Konservasi Lingkungan dan Bangunan Kuno Bersejarah di Surakarta. Gadjah Mada University Press, Yogyakarta.

www.wikipedia.com, 2009 